\title{
KETAHANAN PANGAN DI KOTA PAGARALAM, PROVINSI SUMATERA SELATAN TAHUN 2001-2010
}

\author{
(Food security in Pagaralam City, South Sumatera Province in 2001-2010) \\ Frema Apdita ${ }^{1}$ dan Yayuk Farida Baliwati ${ }^{*}$ \\ 1Departemen Gizi Masyarakat, Fakultas Ekologi Manusia, Institut Pertanian Bogor
}

\begin{abstract}
This study aim to analyze the food resouces in Pagaralam District, South Sumatera Province in 2001-2010. The study design was retrospective with secondary data analysis covering policies, budgeting, food production, exports, imports and number of population. Data processing included analysis for production, exports, imports, food availability and food suffiency by trend, line, ratio availability and ratio of imports. Food availability policy and food availability budgeting were analyzed using content analysis. The results indicate increasing of production on some commodities but supply doesn't fulfill the demand. Food availability increases and energy adequacy has already reached the Minimum Services Standard (90\%), but not for intake protein. Desirable Dietary Pattern (DDP) score is still below 90. The food availability policy and budget do not support the General Policy for Food Security 2006-2010 and still focused on water resources management.
\end{abstract}

Key words: energy and protein adequacy, food availability

\begin{abstract}
ABSTRAK
Penelitian ini bertujuan untuk menganalisis sumberdaya pangan di Kota Pagaralam Provinsi Sumatera Selatan tahun 2001-2010. Data sekunder terdiri dari kebijakan anggaran, produksi pangan, ekspor dan impor pangan serta jumlah penduduk. Desain penelitian ini adalah retrospektif menggunakan data sekunder. Pengolahan data dimulai dengan menganalisis produksi, ekspor dan impor, ketersediaan pangan dan kecukupan pangan menggunakan analisis tren, analisis garis, analisis rasio ketersediaan dan analisis rasio impor. Kebijakan dan anggaran ketersediaan pangan dianalisis menggunakan analisis isi. Peningkatan produksi beberapa komoditi namun produksi belum mencukupi kebutuhan. Ketersediaan pangan mengalami peningkatan dan kecukupan energi sudah mencapai SPM (90\%), akan tetapi kecukupan protein masih defisit. Skor PPH masih di bawah 90. Kebijakan dan anggaran belum sepenuhnya sesuai dengan Kebijakan Umum Ketahanan Pangan (KUKP) 2006-2010 dan masih terfokus pada sektor pengelolaan sumberdaya air.
\end{abstract}

Kata kunci: kecukupan energi dan protein, ketersediaan pangan

"Korespondensi: Departemen Gizi Masyarakat, FEMA, IPB, Bogor, Jl. Lingkar Akademik, Kampus IPB Darmaga, Bogor, 16680. Email: yayuk_gm@yahoo.com 


\section{PENDAHULUAN}

Pemerintah bertanggung jawab mewujudkan ketahanan pangan, hal ini tertuang dalam UU No.7 pasal 45 tentang ketahanan pangan. Oleh karena itu ketahanan pangan merupakan urusan wajib pemerintah. Maxwell dan Frankenberger (1997) menyatakan bahwa dua kelompok indikator ketahanan pangan yaitu indikator proses, menggambarkan situasi pangan yang ditunjukkan oleh ketersediaan dan akses pangan serta indikator dampak meliputi indikator langsung maupun tak langsung.

Output dari ketahanan pangan adalah status gizi, kesehatan dan Indeks Pembangunan Manusia (IPM). Berdasarkan Riskesdas 2010 prevalensi gizi buruk dan gizi kurang Provinsi Sumatera Selatan sebesar $19.9 \%$ dan prevalensi gizi buruk dan kurang Kota Pagaralam sebesar $13.7 \%$ yang merupakan masalah kesehatan masyarakat. Selain itu data BPS tahun 2010 menyatakan IPM Sumatera Selatan belum mencapai kategori baik (80\%) dengan IPM sebesar $72.9 \%$ dengan kategori sedang begitupula dengan IPM Kota Pagaralam pada tahun 2010 sebesar $72.8 \%$ termasuk dalam kategori sedang. Dengan komposisi indikator indeks harapan hidup $68.7 \%$, pendidikan $85.2 \%$ dan pendapatan sebesar $75.1 \%$. Indeks harapan hidup sebesar $68.7 \%$ dan prevalensi gizi buruk dan kurang sebesar $13.6 \%$ mengindikasikan masalah pangan dan gizi Kota Pagaralam belum teratasi dengan baik.

Gibson (2005) menyatakan masalah pangan dan gizi merupakan persoalan ekologi. Masalah pangan dan gizi merupakan hasil akhir dari interaksi beragam faktor dalam suatu ekosistem seperti lingkungan fisik, biologi, sosial dan ekonomi termasuk kendala ekonomi dan politik. Kebijakan dan politik merupakan inti dari hampir semua aspek gizi masyarakat yang berhubungan langsung dengan ketersediaan sumberdaya. Perhatian kebijakan dan politik harus dipusatkan pada optimalisasi sumberdaya serta diintergrasikan dalam program-program yang dirancang. Dalam merancang program pengembangan sumberdaya pangan wilayah diperlukan analisis sumberdaya pangan untuk mengetahui potensi dan hambatan yang ada dalam suatu wilayah.

Oleh karena itu, analisis sumberdaya pangan di Kota Pagaralam diharapkan mampu menjadi salah satu bahan masukan dalam perencanaan program pengembangan sumberdaya pangan untuk mencapai ketersediaan pangan sesuai dengan kebutuhan serta dapat meningkatkan status kesehatan dan IPM Kota Pagaralam.

Penelitian ini bertujuan untuk menganalisis sumberdaya pangan di Kota Pagaralam Provinsi Sumatera Selatan selama tahun 2001-2010. Tujuan khusus adalah menganalisis produksi pangan, ekspor impor, ketersediaan pangan, kebijakan ketersediaan pangan dan anggaran.

\section{METODE}

\section{Desain, Tempat, dan Waktu}

Desain penelitian ini adalah retrospektif (Mann 2003) dengan memanfaatkan data yang tersedia. Pemilihan lokasi penelitian didasarkan atas posisi Pagaralam sebagai salah satu SubTerminal Agribisnis (STA) Sumatera Selatan. Penelitian ini berlangsung selama 2 bulan dari bulan Desember 2011 sampai Januari 2012.

\section{Jenis dan Cara Pengumpulan Data}

Jenis data yang digunakan berasal dari: RPJMD Pagaralam, Renstra Dinas/Badan/Kantor di Kota Pagaralam, produksi pangan, ekspor/impor pangan, anggaran dan data penduduk Pagaralam.

\section{Pengolahan dan Analisis Data}

\section{Analisis produksi pangan Kota Pagaralam}

Analisis tren pertumbuhan. Menyusun data seri produksi pangan selama tahun 2001-2010, lalu dihitung pertumbuhan dan rata-rata pertumbuhan produksi untuk melihat tren perkembangannya, dengan rumus data jumlah tahun dikalikan dengan penjumlahan satu dengan tingkat pertumbuhan dikali jumlah tahun.

Analisis garis. Analisis garis digunakan untuk mengetahui hubungan data awal dengan data akhir sehingga dapat menarik garis lurus sebagai kesimpulan dari perubahan data beberapa tahun. Secara umum persamaan garis linier dari tahun 2000 hingga 2010 adalah konstanta ditambah kemiringan garis tren dikalikan variabel waktu dalam tahun ditambah eror.

Nilai eror dalam suatu persamaan dipengaruhi oleh banyak faktor diantaranya autokorelasi. Asumsi ini diuji dengan teknik statistik Durbin-Watson, yang menyelidiki korelasi berlanjut antar eror (kesalahan):

$$
d=\frac{\sum_{t-2}^{t-N}(e t-e t-1)^{2}}{\sum_{t-1}^{t-N} e_{t}^{2}}
$$

Keterangan: $d=$ nilai Durbin-Watson; $\quad e_{t}=$ residu tahun $t$;

$$
\mathrm{e}_{\mathrm{t}-1}=\text { residu tahun sebelumnya }
$$

Kemudian nilai d dibandingkan dengan nilai-nilai kritis dari dL dan dU dari tabel statistik Durbin-Watson. Dari tabel statistik Durbin-Watson dengan $\mathrm{N}=10$, jumlah variabel bebas $=1$ dan taraf pengujian $(\alpha)=$ $5 \%$, didapatkan nilai kritis $\mathrm{dL}=0.879$ dan nilai kritis $\mathrm{dU}=1.32$ dengan kaidah keputusan: jika $\mathrm{d}<4 \mathrm{DI}$ maka keputusannya autokorelasi positif, jika $d>4 \mathrm{dL}$ maka keputusannya autokorelasi negatif, jika $\mathrm{dU}<\mathrm{d}<4$-Du maka keputusannya tidak ada autokorelasi, dan jika $\mathrm{dL} \leq \mathrm{d} \leq \mathrm{dU}$ atau 4-dU $\leq \mathrm{d} \leq 4$ - $\mathrm{dL}$ maka keputusannya pengujian tidak meyakinkan. 
Penghitungan Rasio Ketersediaan Pangan (RKP). Rasio Ketersediaan Pangan diperoleh dengan membagi ketersediaan pangan dengan konsumsi normatif. Jika nilai RKP lebih dari 1, maka daerah tersebut defisit pangan. Dan bila nilai RKP kurang dari 1, maka ini menunjukkan kondisi surplus pangan.

Analisis ekspor impor pangan menggunakan analisis tren pertumbuhan komoditas ekspor dan impor (\%) dan rasio ketergantungan impor

Perhitungan rumus tren pertumbuhan sama dengan rumus pada perhitungan produksi pangan. Rasio ketergantungan impor diperoleh dari impor dikali $100 \%$ dibagi ketersediaan wilayah.

\section{Analisis ketersediaan pangan Kota Pagaralam}

Ketersediaan pangan merupakan aneka pangan per tahun yang berasal dari produksi. Dalam ketersediaan pangan ideal dilakukan analisis tren. Kecukupan pangan secara kuantitatif dihitung menggunakan tingkat ketersediaaan energi dan tingkat kecukupan protein selama tahun 2001-2010. Tahun 2001-2003 ketersediaan energi perkapita 2800 kkal/hari, protein perkapita $58.5 \mathrm{~g} /$ hari (WNKPG VI tahun 1998). Tahun 2004-2010 ketersediaan energi perkapita $2200 \mathrm{kkal} /$ hari, protein perkapita $57 \mathrm{~g} /$ hari (WNPG VIII tahun 2004). Kecukupan pangan kualitatif dihitung menggunakan skor PPH, dengan skor PPH ideal sebesar 100 dan skor PPH minimal sebesar 90.

\section{Analisis kebijakan ketersediaan dan anggaran kegiatan Pemerintah Kota Pagaralam}

Pengumpulan data dilakukan dengan mengumpulkan berbagai dokumen peraturan perundangan dan kebijakan terkait ketersediaan pangan selama tahun 2008-2010. Informasi tersebut diidentifikasi dan dianalisis dengan metode Content Analysis (Ekomadyo 2009) menggunakan KUKP 2006-2010.

\section{Analisis anggaran program dan kegiatan}

Analisis dilakukan untuk mengetahui besaran dan alokasi anggaran terkait ketersediaan pangan. Data sekunder yang diperoleh dari perda tahun 2001-2010 dilakukan analisis isi menggunakan KUKP 2006-2009.

\section{HASIL DAN PEMBAHASAN}

\section{Situasi Produksi Tanaman Pangan dan Hortikul- tura}

Produksi tanaman pangan dan hortikultura. Ketahanan pangan dari indikator proses digambarkan dalam situasi pangan yang ditunjukkan oleh ketersediaan pangan. Produksi pangan merupakan salah satu komponen utama dalam ketersediaan pangan berdasarkan analisis regresi linier sederhana, diketahui semua jenis pangan sumber karbohidrat kecuali kentang memiliki kecenderungan peningkatan produksi tiap tahunnya (Tabel 1). Komoditas yang paling banyak mengalami peningkatan adalah komoditas padi, ubi kayu, dan ubi jalar yang memiliki potensi untuk dikembangkan. Akan tetapi pada kentang produksinya cenderung menurun selama periode 2001-2010.

Berdasarkan uji Durbin-Watson persamaan garis produksi pangan sumber karbohidrat memiliki autokorelasi positif. Autokorelasi positif berimplikasi pada besarnya eror. Besarnya eror pada persamaan garis berimplikasi pada selang kepercayaan. Selang kepercayaan yang tinggi menyebabkan persamaan garis tidak digunakan untuk memprediksi berapa jumlah (ton/tahun) peningkatan atau penurunan produksi pangan dan hanya dapat digunakan untuk melihat tren naik dan turun produksi pangan dikarenakan kemungkinan kesalahan prediksi persamaan garis produksi pangan semakin tinggi.

Untuk mengkuantifikasi pertumbuhan produksi sesuai kebutuhan penduduk, harus dilakukan dukungan pada faktor saprodi yaitu lahan, benih/ bibit, tenaga kerja, modal, teknologi budidaya dan kebijakan. Menurut Simatupang dan Maulana (2010) masalah utama yang dihadapi oleh sektor pertanian khususnya ketahanan pangan adalah rendahnya kapasitas aktual dibandingkan potensinya. Salah satu penyebab rendahnya kapasitas aktual adalah pembiayaan untuk penerapan teknologi maju rendah, termasuk di dalamnya tidak memadai infrastruktur sistem delivery dan receiving di sektor pertanian, sehingga aliran keluar sektor pertanian tidak lancar. Oleh karena itu harus dilakukan terobosan teknologi, peningkatan potensi intensifikasi, dan ekstensifikasi lahan, dukungan kebijakan komprehensif dan

Tabel 1. Persamaan Garis Produksi Pangan Sumber Karbohidrat

\begin{tabular}{|c|c|c|c|c|c|c|}
\hline \multirow[b]{2}{*}{ No } & \multirow{2}{*}{ Jenis Pangan } & \multicolumn{4}{|c|}{ Tahun 2001-2010 } & \multirow{2}{*}{ Keterangan } \\
\hline & & $B_{0}$ & $B_{1}$ & $R^{2}$ & $\varepsilon(\%)$ & \\
\hline 1 & Padi & -5.2 & 2585.1 & 0.3 & 42.4 & Meningkat \\
\hline 2 & Jagung & -44383.8 & 22.7 & 0.1 & 65.3 & Meningkat \\
\hline 3 & Ubi Kayu & -235135.9 & 118.4 & 0.1 & 43.1 & Meningkat \\
\hline 4 & Ubi Jalar & -1.9 & 956.0 & 0.4 & 107.2 & Meningkat \\
\hline 5 & Kentang & 398790.2 & -198.1 & 0.1 & 51.2 & Menurun \\
\hline
\end{tabular}


terpadu, administrasi pemerintahan terpadu sentralistik serta dukungan politik.

Upaya peningkatan kapasitas produksi pangan harus berpacu dengan pertumbuhan penduduk dan harus memenuhi kebutuhan penduduk untuk mencapai hidup sehat. Pertumbuhan produksi pangan sumber karbohidrat idealnya berada di atas laju pertumbuhan penduduk dalam suatu wilayah selain itu produksi pangan harus mencapai jumlah sesuai dengan konsumsi normatif untuk mencapai hidup sehat. Konsumsi normatif pangan sumber karbohidrat adalah 300 g, dengan komposisi padi-padian sebesar $275 \mathrm{~g}$ dan umbi-umbian $25 \mathrm{~g}$. Kecukupan produksi pangan dalam rangka memenuhi kebutuhan penduduk untuk mencapai hidup sehat dihitung dengan rasio ketersediaan pangan terhadap konsumsi normatif. Produksi pangan sumber karbohidrat sudah mencukupi kebutuhan penduduk untuk mencapai hidup sehat dengan kategori surplus tinggi.

Produksi pangan sumber karbohidrat normatif adalah sebanyak $410 \mathrm{~g} / \mathrm{kap} / \mathrm{hari}$ dengan komposisi padi-padian $300 \mathrm{~g}$ dan umbi-umbian $110 \mathrm{~g}$. Pada tahun 2010 untuk menjamin tercukupinya kebutuhan pangan sumber karbohidrat penduduk Kota Pagaralam sejumlah 126181 jiwa diperlukan produksi pangan sumber karbohidrat sebesar 18883 ton/ tahun dengan komposisi padi-padian 13816.8 ton/ tahun dan umbi-umbian sebesar 5066.2 ton/tahun. Situasi kecukupan produksi pangan sumber karbohidrat yang mengalami surplus pangan mencerminkan bahwa sudah tahan pangan untuk pangan sumber karbohidrat.

Perkembangan produksi kelompok buah-buahan menurut persamaan garis linier cenderung fluktuatif (Tabel 2). Berdasarkan analisis regresi linier sederhana untuk melihat garis persamaan produksi buah-buahan komoditas yang cenderung meningkat tiap tahun adalah jeruk, nanas, manggis, pisang, sawo, rambutan, dan nangka. Sedangkan komoditas menurun tiap tahunnya adalah alpukat, duku, durian, mangga, dan jambu.
Persamaan garis produksi buah-buahan memiliki autokorelasi positif sehingga persamaan garis produksi buah-buahan tidak dapat memprediksi jumlah (ton/tahun) produksi buah-buahan. Pertimbangan lain yang digunakan untuk mengkuantifikasi pertumbuhan produksi sesuai dengan kebutuhan penduduk selain faktor saprodi adalah kondisi biofisik wilayah di antaranya perubahan iklim. Menurut Charay et al. (2010) perubahan iklim yang terjadi sekarang merupakan ancaman utama untuk beberapa dekade ke depan. Perubahan iklim berdampak terhadap sistem kehidupan dan alam dari tingkat global sampai ke tingkat lokal.

Perkembangan produksi kelompok sayuran menurut persamaan garis linier cenderung mengalami peningkatan setiap tahun. Komoditas sayuran yang potensial untuk dikembangkan adalah kubis dan wortel. Hasil uji Durbin-Watson menunjukkan bahwa persamaan garis produksi sayuran memiliki autokorelasi positif, sehingga persamaan tidak dapat memprediksi jumlah (ton/tahun) peningkatan dan penurunan produksi sayuran. Konsumsi normatif buah dan sayur sebagai sumber vitamin dan mineral adalah sebesar $250 \mathrm{~g} / \mathrm{kap} /$ hari. Laju produksi pangan dari tahun 2001-2010 ada di atas laju pertumbuhan penduduk. Berdasarkan analisis rasio ketersediaan pangan diketahui bahwa situasi produksi pangan sumber vitamin dan mineral sudah mencapai surplus pangan. Produksi buah dan sayuran Kota Pagaralam surplus tinggi yang mampu mencukupi standar kecukupan $275 \mathrm{~g} / \mathrm{kap} / \mathrm{hari}$ atau $100.4 \mathrm{~kg} / \mathrm{kap} /$ tahun. Pada tahun 2010 dengan jumlah penduduk sebesar 126121 jiwa produksi buah dan sayuran harus dicapai adalah sebesar 12655.4 ton/tahun. Pada tahun 2010 produksi buah dan sayuran lebih besar dari produksi yang ditetapkan yaitu sebesar 1 848575.6 ton/tahun, hal ini mengindikasikan Kota Pagaralam tahan pangan dan mandiri pangan untuk kelompok pangan buah dan sayuran karena mampu memenuhi kebutuhan dari produksi lokal.

Tabel 2. Persamaan Garis Produksi Buah-buahan

\begin{tabular}{|c|c|c|c|c|c|c|}
\hline \multirow{2}{*}{ No } & \multirow{2}{*}{ Jenis Pangan } & \multicolumn{4}{|c|}{ Tahun 2001-2010 } & \multirow{2}{*}{ Keterangan } \\
\hline & & $B_{0}$ & $B_{1}$ & $\mathbf{R}^{2}$ & $\varepsilon(\%)$ & \\
\hline 1 & Alpukat & 14989 & -11910 & 0.14 & 0.0 & Menurun \\
\hline 2 & Jeruk & 788.3 & 548.4 & 0.03 & 206.8 & Meningkat \\
\hline 3 & Duku & 173.9 & -1569 & 0.00 & 211.2 & Menurun \\
\hline 4 & Durian & 15054 & -444.6 & 0.00 & 200.6 & Menurun \\
\hline 5 & Mangga & 43463 & -2220 & 0.02 & 177.0 & Menurun \\
\hline 6 & Nanas & 627.6 & 85.71 & 0.01 & 226.4 & Meningkat \\
\hline 7 & Manggis & 0.866 & 0.187 & 0.01 & 263.9 & Meningkat \\
\hline 8 & Pisang & 24859 & 4627 & 0.02 & 0.0 & Meningkat \\
\hline 9 & Rambutan & 29301 & 7673 & 0.00 & 0.0 & Meningkat \\
\hline 10 & Sawo & 10606 & 232.3 & 0.00 & 210.8 & Meningkat \\
\hline 11 & Nangka & 1988 & 4106 & 0.03 & 287.5 & Meningkat \\
\hline 12 & Jambu & 2348 & -196.8 & 0.03 & 262.6 & Menurun \\
\hline 13 & Pepaya & -29609 & 12646 & 0.30 & 0.0 & Meningkat \\
\hline 14 & Lainnya & 14989 & -11910 & 0.14 & 0.0 & Menurun \\
\hline
\end{tabular}


Berdasarkan analisis regresi selama sepuluh tahun menunjukkan bahwa rata-rata produksi peternakan memiliki tren yang cenderung naik. Persamaan garis produksi peternakan memiliki autokorelasi positif sehingga hanya dapat digunakan untuk melihat tren naik dan turun produksi pangan. Oleh karena itu pengkuantifikasian pertumbuhan produksi peternakan bergantung pada faktor saprodi antara lain lahan, tenaga kerja, modal, teknologi budidaya, kebijakan, dan anggaran.

Perkembangan produksi perikanan menurut persamaan garis linier cenderung mengalami penurunan dalam kurun tahun 2001-2010. Produksi perikanan dapat dipengaruhi oleh banyak faktor antara lain kondisi biofisik wilayah. Berdasarkan hasil uji Durbin-Watson persamaan garis produksi perikanan juga memiliki autokorelasi positif.

Konsumsi normatif untuk pangan sumber protein hewani adalah sebesar $150 \mathrm{~g}$. Ketersediaan pangan sumber protein hewani berasal dari produksi peternakan (daging ruminansia, unggas, jeroan, dan telur) dan perikanan (ikan budidaya dan tangkap). Ketersediaan pangan sumber protein hewani ideal adalah sebesar $165 \mathrm{~g} / \mathrm{kap} / \mathrm{hari}$ atau $60.2 \mathrm{~kg} / \mathrm{kap} /$ hari. Berdasarkan analisis situasi produksi pangan sumber hewani belum mampu mencukupi kebutuhan sesuai konsumsi normatif $165 \mathrm{~g} / \mathrm{kap} / \mathrm{hari}$ atau 1013.2 ton/tahun dengan kategori defisit tinggi (jumlah penduduk sebesar 126121 jiwa pada tahun 2010). Selisih ketersediaan aktual dan ideal adalah sebesar 4214.2 ton/tahun untuk mencapai ketersediaan ideal. Hal ini mengindikasikan produksi pangan sumber protein hewani belum mencukupi kebutuhan dan belum mencapai ketahanan pangan.

Simatupang dan Maulana (2010) menyebutkan bahwa masalah produksi peternakan adalah wabah penyakit, kendala padang penggembalaan dan sumber pakan hijauan, keterbatasan kapasitas usaha sampingan, konsentrasi industri dan praktek persaingan tidak sehat dan belum berkembangnya sistem inovasi. Oleh karena itu untuk meningkatkan produksi peternakan perlu dilakukan kebijakan, program serta anggaran yang dialokasikan untuk mengatasi masalah tersebut. Selain peningkatan produksi pemenuhan kebutuhan penduduk dapat diadakan melalui impor pangan.

\section{Ekspor Impor Pangan}

Komoditas pangan yang diekspor oleh Pagaralam adalah kelompok pangan serealia, umbi-umbian, buah, dan sayuran. Secara umum pertumbuhan ekspor komoditas pangan mengalami peningkatan, akan tetapi terjadi penurunan untuk komoditas ketimun sebesar $100.0 \%$, daun bawang $4.7 \%$, dan buncis $200.0 \%$.

Tingkat pertumbuhan impor meningkat pada kurun waktu 2009-2010. Tingkat pertumbuhan impor paling tinggi pada komoditas tepung gandum
(100.0\%), jagung (100.0\%), kacang tanah (100.0\%), dan daging ayam ras (100.0\%). Selain itu pada komoditas gula pasir, kedelai, bawang merah, bawang putih dan daging sapi mengalami peningkatan impor yang cukup tinggi (>90\%). Rasio ketergantungan impor paling tinggi pada komoditas tepung gandum, gula pasir, dan bawang putih. Hal ini menunjukan Kota Pagaralam belum mampu untuk memenuhi kebutuhan komoditas tersebut. Komoditas lain yang memiliki rasio ketergantungan impor yang tinggi adalah minyak sawit (87.7\%), susu (75.0\%), kedelai (92.0\%), dan bawang merah (77.4\%). Menurut Yusuf dan Widyastutik (2007) impor pangan dapat menurunkan neraca perdagangan, hal ini akan menyebabkan penurunan pendapatan suatu daerah.

\section{Situasi Ketersediaan Pangan}

Berdasarkan PP No. 68 Tahun 2002, penyediaan pangan dilakukan dengan mengembangkan sistem produksi pangan yang bertumpu pada sumberdaya, kelembagaan dan budaya lokal, efisiensi sistem usaha pangan, teknologi produksi pangan, sarana dan prasarana produksi pangan, mempertahankan dan mengembangkan lahan produktif. Ketersediaan pangan pada penelitian ini berasal produksi pangan lokal yang merupakan bentuk swasembada absolut atau kemandirian pangan.

Standar ketersediaan untuk tahun 2001-2003 adalah energi sebesar 2800 kkal. Kondisi ketersediaan energi dalam kurun waktu tahun 2001-2003 mengalami peningkatan. Pada tahun 2001 total energi masih dibawah standar yaitu 2800 kkal/kap/ hari, ketersediaan pangan pada tahun 2002 dan 2003 mengalami peningkatan dan berada di atas standar yaitu $2800 \mathrm{kkal} / \mathrm{kap} / \mathrm{hari}$. Besarnya laju pertumbuhan ketersediaan pangan tahun 2001-2003 adalah sebesar $53.0 \%$ dan berada di atas laju pertumbuhan penduduk Kota Pagaralam 0.8\% yang menunjukkan potensi besar untuk mencapai kemandirian pangan wilayah. Standar ketersediaan untuk tahun 20042010 adalah energi sebesar 2200 kkal. Dalam kurun waktu tahun 2004-2010 kondisi ketersediaan energi cukup fluktuatif. Pada tahun 2004-2010 total energi diatas standar 2200 kkal/kap/hari. Laju ketersediaan pangan Kota Pagaralam tahun 2004-2010 sebesar $72.4 \%$ yang berada di atas laju penduduk sebesar $0.8 \%$.

Maxwell dan Frankenberger (1997) menyatakan bahwa ketahanan pangan dapat dilihat dari dua indikator, diantaranya indikator proses yang menggambarkan situasi pangan dan dapat ditunjukkan oleh ketersediaan (produksi pertanian, iklim, dan akses terhadap sumberdaya). Kecukupan pangan wilayah pada penelitian ini adalah kondisi tercapainya ketersediaan pangan sesuai dengan standar (menurut tahun pengambilan data) yang merupakan tolak ukur ketahanan pangan dari indikator proses. Tingkat Ketersediaan Energi (TKE) dan Tingkat Ke- 
Tabel 3. Tingkat Kecukupan Energi dan Protein

\begin{tabular}{ccccccc}
\hline Tahun & \%TKE & Kategori & SPM & \%TKP & Kategori & SPM \\
\hline 2001 & 95.0 & Normal & Tercapai & 88.4 & Defisit ringan & Belum tercapai \\
2002 & 127.0 & Over & Tercapai & 126.3 & Over & Tercapai \\
2003 & 218.9 & Over & Tercapai & 320.2 & Over & Tercapai \\
2004 & 150.2 & Over & Tercapai & 240.7 & Normal & Tercapai \\
2005 & 94.8 & Normal & Tercapai & 68.7 & Defisit berat & Belum tercapai \\
2006 & 164.7 & Over & Tercapai & 124.5 & Over & Tercapai \\
2007 & 778.2 & Over & Tercapai & 376.7 & Over & Tercapai \\
2008 & 122.1 & Over & Tercapai & 102.6 & Normal & Tercapai \\
2009 & 226.4 & Over & Tercapai & 191.4 & Over & Tercapai \\
2010 & 549.6 & Over & Tercapai & 849.1 & Over & Tercapai \\
\hline
\end{tabular}

tersediaan Protein (TKP) merupakan perbandingan ketersediaan energi dan protein aktual dengan standar kemudian dibandingkan dengan SPM (90\%). Tingkat kecukupan pangan wilayah dapat dilihat pada Tabel 3.

Tabel 3 menunjukkan kecukupan protein masih fluktuatif yang dapat dilihat dari nilai dan kategori TKP. TKP tahun 2001 dan 2005 masih dalam kategori defisit dan belum mencapai standar sesuai dengan SPM sebesar 90\%. Hal ini mengindikasikan bahwa secara kuantitas kecukupan pangan belum tercukupi dan belum mencapai kategori tahan pangan. Hal ini selaras dengan PPH Kota Pagaralam yang belum mencapai standar pelayanan minimal dengan skor PPH sebesar 90. Pola Pangan Harapan (PPH) adalah susunan beragam pangan yang didasarkan pada sumbangan energi dari kelompok pangan dari ketersediaan maupun konsumsi pangan. Hasil pencapaian skor PPH ketersediaan dalam kurun tahun 2001-2010 fluktuatif dengan rata-rata pertumbuhan 2.3\%. Skor PPH Kota Pagaralam belum mencapai ideal (100) dan mencapai skor minimal (90). Hal ini menunjukkan bahwa ketersediaan pangan di Kota Pagaralam belum beragam.

Berdasarkan analisis kecukupan ketersediaan pangan secara kuantitatif yang menunjukkan bahwa TKE Kota Pagaralam sudah mencapai SPM dan memiliki potensi yang besar untuk dikembangkan dalam rangka pencapaian ketahanan pangan berbasis produksi lokal (kemandirian pangan). Namun demikian TKP Kota Pagaralam masih dalam kategori defisit dan belum mencapai SPM pada tahun 2001 dan 2005. Analisis kualitatif menunjukkan bahwa skor PPH Kota Pagaralam masih dibawah skor PPH minimal (90) dapat diketahui bahwa Kota Pagaralam belum mencapai ketahanan pangan dari indikator proses.

\section{Kebijakan Ketersediaan Pangan}

Menurut PP No. 38 tahun 2007 disebutkan bahwa ketahanan pangan merupakan urusan wajib pemerintah daerah. Ketersediaan pangan merupakan subsistem dari ketahanan pangan. Pencapaian ketersediaan pangan suatu wilayah dipengaruhi oleh kebijakan-kebijakan yang mendukung keterse- diaan pangan wilayah. Menurut Idjudin dan Marwanto (2008) implementasi kebijakan normatif dan teknologi yang serba cukup (comprehensive) yang didukung kebijakan mikro (program jangka pendek) dan kebijakan makro (program jangka panjang) dapat meningkatkan produktivitas pertanian dalam rangka penjaminan ketersediaan pangan. Kebijakan ke-tersediaan pangan berperan dan berfungsi sebagai manajemen pencapaian ketersediaan pangan sesuai dengan standar pelayanan minimal ketahanan pa-ngan.

Kebijakan yang ada harus sejalan dengan visi dan misi Kota Pagaralam. Visi dan misi dirancang sesuai kondisi saat ini, isu lima tahun mendatang dan penggalian aspirasi serta persepsi masyarakat. Visi Kota Pagaralam pada tahun 2008-2013 adalah "Pagaralam sebagai Kota Agribisnis dan Pariwisata bernuansa Islami". Berdasarkan analisis isi visi dan misi Kota Pagaralam diketahui bahwa fokus utama pembangunan Kota Pagaralam adalah sektor agribisnis dan pariwisata. Pengembangan sektor agribisnis bertumpu pada sumberdaya pangan yang ada, oleh karena itu untuk mencapai visi dan misi tersebut pengembangan sumberdaya pangan sangat diperlukan. Dalam RPJMD Kota Pagaralam tahun 2008-2013 tercantum penjabaran misi Kota Pagaralam dalam tujuan-tujuan serta strategi utuk mencapai tujuan Kota Pagaralam, termasuk misi yang terkait dengan ketersediaan pangan. Tujuan dan strategi yang terpilih menggunakan KUKP 2006-2010. Berdasarkan analisis isi diketahui bahwa tujuan dan strategi yang terkait dengan ketersediaan pangan belum sepenuhnya sesuai dengan KUKP. Tujuan dan strategi dalam RPJMD Kota Pagaralam hanya bertumpu pada sektor infrastruktur (sistem irigasi dan jalan) dan pengembangan agribisnis, belum mencakup semua indikator yang ada dalam KUKP 2006-2010 terutama indikator peningkatan produktivitas, teknologi, dan budidaya.

Pencapaian ketersediaan pangan harus didukung oleh seluruh Satuan Kerja Perangkat Daerah (SKPD) terkait. Dalam penelitian ini SKPD terkait ketersediaan pangan adalah Dinas Tanaman Pangan, Dinas Peternakan dan Perikanan, Dinas Kehutanan dan Perkebunan, Badan Ketahanan Pangan, Dinas 
Keuangan, Bagian Sosial dan Dinas Pekerjaan Umum. Tujuan dan strategi dalam RPJMD diterjemahkan dalam setiap program SKPD terkait. Pemilihan program yang terkait dengan ketersediaan menggunakan KUKP 2006-2010, lalu dilakukan perbandingan antara program SKPD dengan program yang ada di KUKP 2006-2010. Persentase kesesuaian program dari persentase tertinggi dilakukan oleh Dinas Tanaman Pangan, Peternakan, dan Perikanan (91\%), Dinas Pekerjaan Umum (PU) (75\%), Dinas Kehutanan dan Perkebunan serta Badan Ketahanan Pangan (67\%), Bagian Sosial (50\%), dan Dinas Keuangan (0\%). Hal ini mengindikasikan komitmen SKPD terkait dalam penjaminan ketersediaan pangan Kota Pagaralam.

\section{Anggaran Ketersediaan Pangan}

Menurut Dermoredjo (2003) perekonomian merupakan salah satu indikator mengenai kebijakan yang telah dikeluarkan pemerintah sudah mampu memenuhi kebutuhan dan memperbaiki taraf hidup masyarakat atau tidak. Salah satu bentuk dukungan pemerintah di bidang ekonomi dalam penjaminan ketersediaan pangan wilayah adalah besarnya anggaran keuangan daerah yang terkait ketersediaan pangan. Analisis isi dokumen dengan menggunakan acuan KUKP 2005-2009 dilakukan dalam rangka mengetahui seberapa besar kebijakan anggaran Pemerintah Daerah Kota Pagaralam untuk mendukung ketersediaan pangan. Berdasarkan informasi tersebut, diperoleh acuan program dan kegiatan penjaminan ketersediaan pangan. Jumlah APBD Kota Pagaralam selama kurun waktu 10 tahun dari tahun 2001-2010 terus mengalami peningkatan. Merujuk total APBD tertinggi terdapat pada tahun 2009 yakni Rp 465.5 M dan dana ketersediaan sebesar Rp 17.9 $M$ dengan persentase alokasi dana tertinggi pada tahun 2003 sebesar $7.75 \%$.

Kota Pagaralam memiliki lima instansi yang memiliki alokasi anggaran terkait ketersediaan pangan. Alokasi terbesar bersumber dari anggaran Dinas Pekerjaan Umum (PU) yang bertanggung jawab untuk mengelola dan memelihara sumberdaya perairan. Fokus utama pemerintah terkait ketersediaan pangan adalah pembangunan infrastuktur khususnya sumberdaya perairan. Dinas Tanaman Pangan serta Dinas Peternakan dan Perikanan mendapatkan alokasi terbesar kedua setelah Dinas PU, hal ini menunjukkan komitmen pemerintah untuk meningkatkan produksi dan produktivitas sektor tersebut.

Meningkatnya anggaran ketersediaan pangan terkait dengan ketersediaan pangan Kota Pagaralam. Uji persamaan garis linier diketahui nilai $\mathrm{R}^{2}$ pada persamaan garis anggaran dengan tingkat ketersediaan tergolong sangat kecil, yang menunjukkan bahwa besar anggaran bukan faktor dominan yang memengaruhi tingkat ketersediaan.

\section{KESIMPULAN}

Sumberdaya pangan Kota Pagaralam belum mampu mewujudkan ketahanan pangan dari indikator proses. Berdasarkan analisis rasio ketersediaan produksi pangan sumber karbohidrat dan sumber vitamin dan mineral tergolong surplus tinggi sedangkan produksi sumber protein hewani tergolong defisit tinggi. Produksi pangan sumber protein hewani defisit tinggi menunjukkan produksi pangan belum memenuhi kecukupan kebutuhan pangan penduduk (20\%) dengan PPH 66.7.

Kota Pagaralam mampu mengekspor beberapa komoditi pangan yaitu ubi kayu, ubi jalar, alpukat, dan kol. Pagaralam masih bergantung terhadap impor tepung gandum, gula pasir, bawang putih, minyak sawit, susu, kedelai bawang merah, daging unggas dan daging sapi. Ketersediaan pangan untuk konsumsi penduduk Kota Pagaralam belum mencapai SPM.

Berdasarkan hasil analisis isi RPJMD dan Renstra SKPD terkait ketersediaan pangan, kebijakan dan anggaran dana Kota Pagaralam belum sepenuhnya mendukung ketersediaan pangan wilayah. Tujuan dan strategi terkait ketersediaan pangan bertumpu pada infrastruktur irigasi dan jalan serta pengembangan agribisnis.

Produksi dan penyediaan pangan sumber protein harus diprioritaskan, yang dapat dilakukan dengan peningkatan anggaran dan program-program terkait ketersediaan pangan sumber protein.

Ketepatan analisis sumberdaya pangan sangat bergantung pada manajemen data pokok yang terkait ketersediaan pangan. Oleh karena itu manajemen data sangat diperlukan. Data produksi, ekspor dan impor pangan harus selalu dilaporkan secara berkala dan berkelanjutan.

\section{DAFTAR PUSTAKA}

Charay et al. 2010. The threats of climate change on undernutrition a neglected issue that requires furhter analysis and urgent actions: SCN News, 28(3), 4-17.

Dermoredjo SK. 2003. Analisis kebijakan hubungan antarsektor perekonomian nasional. Analisis Kebijakan Pertanian, 1(4), 345-362.

Ekomadyo AS. 2006. Prospek penerapan metode analisis (content analysis) dalam penelitian media arsitektur. Jurnal Ilmu Pengetahuan Teknologi dan Seni, 10(2), 51-57.

Gibson RS. 2005. Principles of Nutritional Assessment. Oxford University Press, New York.

Idjudin AA \& Marwanto S. 2008. Reformasi pengelolaan lahan kering untuk mendukung swasembada pangan. Jurnal Sumberdaya Lahan, 2(2), 115-125.

Maxwell S \& Frankenbeger TR. 1997. Household and Food Security: Indicators and Data Collection Methods for Assesing Household Food Security Dalam Simon Maxwell dan Timohu R. Frankenberger (Eds.), Household Food Security: Concepts, Indicators, Measurements. Unicef, New York.

Mann CJ. 2003. Obervational research method. Emergency Medicine Journal, 20(38), 54-60.

Pranadji T. 2003. Otonomi daerah dan daya saing 
Apdita \& Baliwati

agribinis. Analisis Kebijakan Pertanian, 1(2), 152-166.

Rahayu S. 2009. Penggunaan Metode Durbin Watson dalam Menyelesaikan Model Regresi yang Mengandung Autokorelasi [Skripsi]. FMIPA, Universitas Sumatera Utara, Medan.

Simatupang P \& Maulana M. 2010. Prospek penawaran dan permintaan pangan utama. analisis masalah, kendala dan opsi kebijakan revitalisasi produksi. Pusat Analisis Ekonomi dan Kebijakan Pertanian, 1(1), 15-35.

Yusuf \& Widyastutik. 2007. Analisis ekspor dan impor komoditas pangan utama dan liberalisasi perdagangan terhadap neraca perdagangan Indonesia. Jurnal Manajemen Agribisnis, 4(1), 46-56. 